\title{
Brainstorming and Essay Writing in EFL Class
}

\author{
Salem Saleh Khalaf Ibnian \\ Faculty of Arts and Sciences, Middle East University, P.O. Box 383, Amman, 11831, Jordan \\ Email: salem_ibnian@yahoo.com
}

\begin{abstract}
The current study aimed at investigating the effect of using the brainstorming technique on developing first secondary grade students' essay writing skills in EFL. The study attempted to answer the following questions: 1-What are the essay writing skills needed for first secondary grade students in EFL? 2What is the effect of using the brainstorming technique on developing first secondary grade students' essay writing skills in EFL? Tools of the study included a checklist to identify the essay writing sills needed for first secondary grade students in EFL as well as a pre- post essay writing test and its scoring scale. Results revealed the effect of using the brainstorming technique on developing first secondary grade students' essay writing skills in EFL.
\end{abstract}

Index Terms - brainstorming technique, first secondary grade, essay writing

\section{INTRODUCTION}

\section{A. Brainstorming and Essay Writing}

Language has an essential role in helping learners develop their thinking and creative skills through using the language in several processes such as, relating, commenting, connecting, predicting, recalling, comprehending, applying, associating, analyzing, synthesizing, evaluating and solving problems.

Bello (1997) indicated that writing, as a productive language skill, plays an essential role in promoting language acquisition as learners experiment with words, sentences, and large chunks of writing to communicate their ideas effectively and to reinforce the grammar and vocabulary they learn in class. He added that "one of the major failing in the traditional curriculum could be attributed to lack of attention given to writing, which is an important avenue for thinking".

As for writing in EFL, French and Rhoder (1992) stated that writing could be viewed as the main area in the curriculum that we associate with creativity, noting that writing is one of the most tasks that we can be asked to perform.

Thus, improving students' essay writing is believed to be one of the most important skills which EFL learners need to develop throughout their schooling.

During their schooling, EFL learners need to develop some writing skills such as: the ability to write complete and meaningful sentences, coherent, clear and well- organized ideas, use communicative language, choose suitable words and idioms and use writing mechanics appropriately.

Darayseh (2003) noted that teaching writing no longer means simply having students do grammar exercises in writing or getting writing which is free from grammar, punctuation and spelling mistakes, instead, we are after writing about what students are interested in and what they really want to communicate to the reader, and how they reach their final writing products.

In spite of the importance of the activities included in the various writing stages, many teachers give little or even no attention to such stages.

Colantone (1998) cited that many EFL teachers follow the traditional method in teaching composition concentrating on the final product rather than on the process of writing. "In writing classes, teachers emphasize mechanics, spelling, punctuation, grammar, sentence structure, width of margins, and so on, with little attention to development or style.

In addition, the stages of writing: pre-writing, while writing, and post-writing are expected to contribute to strengthening students' thinking skills because they engage them in processes such as connecting, analyzing and evaluating ideas, a fact that leads to sharpening students thinking skills.

With regard to means to help learners generate ideas, Manktelow (2003) highlighted some strategies that could be followed to develop students' creativity such as: problem solving, attribute listing, morphological analysis, brainstorming, and checklists.

Thus, the current study comes as an attempt to investigate the effectiveness of using the brainstorming technique in developing first secondary grade students' essay writing skills in EFL.

1. Essay writing:

The essay is defined as a short literary composition on a subject expressing a personal view. The essay consists of the following parts:

- The introduction.

- The body.

- The conclusion. 


\subsection{The introduction:}

The purpose of the introduction is to introduce the reader to the essay. It tells the reader what the essay is about and why he or she should read it. From reading an introduction, the reader should be able to determine the thesis statement of the essay and the main points that will be discussed, and the order in which they will be discussed.

The thesis is a clear concise statement of the position that the writer will defend in the essay. It also contains the focus of the essay and tells the reader what the essay is going to be about. The thesis statement is usually stated clearly in one or two sentences at the end of the essay's introduction.

1.2. The Body:

The body is where the supporting points and details are found. Through body paragraphs, the reader gets more specific information and can form an opinion. Paragraphs must be logically arranged and provide a seamless framework for ideas. Each paragraph should include a topic sentence indicating the main idea of the paragraph.

\subsection{The Conclusion:}

The conclusion serves two specific functions: 1) it summarizes what has been said in the body of the essay without repeating it. 2) it provides the reader with a relevant final thought on what the writer wants him/ her to do, think, believe, or understand.

2. Essay Types:

Essays could be classified into four types:

1- The Expository Essay.

2- The Descriptive Essay.

3- The Argumentative Essay.

4- The Narrative Essay.

The expository essay, which is also called the analytical or information essay, is that kind which explains and analyzes a specific issue. It requires students to investigate an idea, evaluate evidence, expound on the idea, and set forth an argument concerning that idea. This can be accomplished through comparison and contrast, definition, the analysis of cause and effect, etc...

On the other hand, the descriptive essay is that kind which describes an object, person, place, experience, emotion, situation, etc...

As for the argumentative essay, it is that one which attempts to persuade the reader of the writer's point of view. The writer tries to convince the reader of the validity of his / her opinion.

Finally, the narrative essay is that kind which tells a story. Generally the narrative essay is conversational in style, and tells of a personal experience. This essay could tell of a single, life-shaping event, or simply a daily experience.

3. Brainstorming Technique:

Brainstorming is a technique used to encourage individuals to generate ideas and come up with a list of possible solutions to a certain problem.

In 1953 the technique was popularized by Alex Osborn in a book called "Applied Imagination". Osborn proposed that groups could double their creative output with brainstorming.

During the brainstorming session, a number of rules should be taken into account including:

- No criticism of ideas.

- Building on what others have suggested.

- Strange and wild ideas are accepted.

- Welcoming the large quantities of ideas.

\section{B. Need for the Study}

In the light of the researcher's observations and experience in the field of English language teaching, he observed the little attention attached to essay writing in EFL composition classes in Jordanian schools.

Moreover, the researcher analyzed a random sample of first secondary grade students' composition papers in EFL. Results showed that most students were not able to come up with deep, coherent and logically sequenced ideas.

In addition, a number of studies, which were conducted in TEFL field called for creating a motivating climate and using suitable technique to develop learners' language skills including writing.

Khwaileh (1991) highlighted the importance of the pre-writing stage, pointing out that "nearly most teachers of English as a Foreign Language usually ask their students to write a short composition on a certain topic without giving the adequate support or help apart from the meaning of a few related words". Accordingly, students who are not given the opportunity to generate ideas about the given topic, record them and refine them, usually face a great difficulty in writing comprehensive and logical sentences.

Alsouqi (2001) stated that one reason for Jordanian students' writing problems might be the use of a traditional approach of composition instruction. He noted that "through this traditional approach, teachers roughly explain what features characterize a good text, emphasizing the importance of correct grammar and spelling".

Based on the above-mentioned argument, the current study comes to examine the effectiveness of using the brainstorming technique in developing learners essay writing skills in EFL class.

C. Statement of the Problem 
The problem of the study could be stated in the low level of first secondary grade students in Jordan in essay writing in EFL.

Consequently, the present study attempted to answer the following main question:

-What is the effectiveness of using the brainstorming technique in developing first secondary grade students' essay writing skills in EFL?

Two questions were derived from the main question:

1 -What are the essay writing skills needed for first secondary grade students in EFL?

2- What is the effect of using the brainstorming technique on developing first secondary grade students' essay writing skills in EFL?

\section{Aims of the Study}

The current study aimed at:

1- Identifying essay writing skills needed for first secondary grade students in EFL

2- Developing Jordanian first secondary grade students' essay writing skills in EFL.

\section{E. Significance of the Study}

The current study is expected to help in the following areas:

1. Ministry of Education: Helping the Ministry develop outcomes of the educational process in Jordan.

2. Supervisors and curriculum planners: -Providing them with the essay writing skills needed to be taken into consideration while planning EFL curriculum.

3. EFL Teachers: Helping them follow suitable techniques for developing students' essay writing skills in EFL.

4. Students: Developing their essay writing skills in EFL

5. Researchers: Paving the way for other researchers to conduct further studies on developing students' writing skills.

\section{F. Limitations of the Study}

1-The study was confined to developing students' essay writing skills.

2- The study was confined to four classes of first secondary grade students randomly chosen from Amman public education schools. (Two classes for the experimental group and the other ones for the control group)

3-The study was conducted in the first term of the academic year 2010-2011, two months, two periods per week, 45 minutes each.

\section{METHODOLOGY}

\section{A. Sample of the Study}

The sample of the study consisted of 84 first secondary grade students classified into four classes, two served as an experimental group and the other ones as control.

The students were assigned randomly from Amman public education schools.

\section{B. Tools of the Study}

1- A checklist to identify the essay writing skills needed for first secondary grade students in EFL.

2- A pre- post essay writing test and its scoring scale.

The tools were developed by the researcher.

\section{Hypotheses of the Study}

1-There is statistically significant difference between the mean scores of the experimental group and the control group on the post- test in essay writing in favor of those of the experimental group.

2-There is statistically significant difference between the mean scores of the experimental group on the pre- test and post- test in essay writing in favor of their post- test scores.

\section{Variables of the Study}

1- The independent variable:

- The brainstorming technique

2- The dependent variable:

- Performance of the experimental group on the essay writing post- test.

\section{E. Method of the Study}

1- The study followed the descriptive method in collecting data on writing in EFL general, and essay writing in particular.

2-The study also followed the quasi- experimental design. Two groups were chosen from Amman public education schools. One served as an experimental group and the other one as control. The researcher administered a pre- post test to the experimental and control groups to test the effectiveness of using the brainstorming technique, which was applied to the experimental group. 


\section{F. Definition of Terms}

- Effect: the change caused by the use of the brainstorming technique on developing first secondary grade students' essay writing skills in EFL.

- Brainstorming is a group creativity technique designed to generate a large number of ideas to solve a certain problem.

\section{G. Procedures of the Study}

To answer the main question of the study, the following procedures were followed:

1- To answer the first question: "What are the essay writing skills needed for first secondary grade students in EFL?" the researcher has:

1)- Reviewed the related literature in the field of creative writing in general.

2)- Reviewed the related literature in the field of essay writing in EFL in particular.

3)- Designed a checklist including the essay writing skills needed for first secondary grade students in EFL.

4)- Submitted the checklist to specialized jury members to identify the essay writing skills needed for first secondary grade students in EFL.

2- To answer the second question: "What is the effect of using the brainstorming technique on developing first secondary grade students' essay writing skills in EFL?" the researcher has:

1)- Reviewed the related literature that includes tests to measure students' writing skills in general and essay writing skills in particular.

2)- Prepared the pre- post test.

3)- Submitted the test to specialized jury members to ensure its validity and made the necessary modifications in the light of their observations.

4)- Ensured the reliability of the test.

5)- Chosen a random sample (control and experimental groups).

6)- Administered the essay pre- test writing to both groups.

7)- Applied the proposed technique.

8)- Administered the essay post- test writing to both groups.

9)- Collected and analyzed data.

10)- Discussed the results of the study.

11)- Introduced recommendations and suggestions for further research.

\section{H. Review of Related Studies}

Reynolds (1983) conducted a study to determine the comparative effects that two methodologies (Expressive Writing Methodology and Traditional Writing Methodology) have on the ability of high school students to write stories and essays. The study also aimed at determining if an interaction exists between sex and method of instruction and English achievement level (high achiever or low achiever) and method of instruction on essay and story writing ability.

Subjects 'forty-eight students' were classified into two different groups: one group was instructed by the Expressive Writing Methodology and the other group was instructed by the Traditional Writing Methodology. They were given a pretest story and essay, received a twelve-week period of writing instruction, and then were given an identical posttest.

The main difference between the two groups was that the expressive group participated in expressive writing exercises while the traditional group participated in traditional worksheet exercises. Both groups were involved in the writing process.

No significant differences in story and essay posttest scores between the two groups were observed. No significant interaction effect on story and essay posttest scores between sex of the student and method of instruction was observed, and no significant interaction effect on essay posttest scores between English achievement level and method of instruction was observed. However, a significant interaction effect on story posttest scores between English achievement level and method of instruction was observed.

El Abed (1991) investigated the effect of selected prewriting activities (class discussion and pair discussion) and the effect of no prewriting activity on the quantity and quality of students composition.

The sample of the study consisted of sixty first year students in Hakama Vocational Training Center in Jordan. The students were randomly assigned to one of the three groups: 1) class discussion. 2) pair discussion. 3) No prewriting activity (as control group).

Students of each group completed four compositions, one in each week for four weeks. The first composition (pretest) was followed by three treatments, each 20 minutes long. After each treatment, the students wrote a composition. The last composition was the posttest.

The compositions were evaluated for quantity (number of words in the composition) and quality (general impression holistic scoring). The composition writing time was ten minutes.

Results of the study showed no significant differences in writing quantity between the selected prewriting activities, class discussion and pair discussion, and the control group.

No significant differences were found in writing quality between the selected prewriting activities and the control group. No significant differences were found among the selected prewriting activities (class discussion and pair 
discussion) for either writing quantity and writing quality.

Holden (1996) compared the effectiveness of two approaches to teaching writing (formal grammar instruction and the process approach) in students' knowledge of grammar and writing improvement.

The sample of the study consisted of 70 college students divided into two groups: experimental and control. The experimental group was taught using the process approach. No formal grammar instruction was given to the experimental group.

Results indicated that the experimental group scored a higher number of correct answers on the posttest than the control group did. Furthermore, the experimental group attempted to answer more test questions on the posttest than the control group did.

Furthermore, findings revealed that the process approach to teaching writing, which deemphasizes formal grammar instruction, is more effective in improving students' knowledge of grammar than formal grammar instruction

Shi (1998) assessed whether peer talk and teacher-led prewriting discussions affect the quality of students' compositions.

Forty-seven adult ESL students from three pre-university writing classes participated in the study. Each student wrote three drafts of opinion essays under conditions of peer discussion, teacher-led discussion, and no discussion.

Nonparametric tests of rating scores showed no statistically significant differences overall in the writing under the three conditions. However, students were found to write longer drafts in the condition of no discussion, shorter drafts after teacher-led talk, and drafts with a greater variety of verbs after peer talk.

Comparison of students' use of verbs in both written and spoken texts traced the effects of various prewriting conditions, whereas the no discussion condition led to longer drafts (presumably because students had more time to write than in the talk-write sessions). Prewriting discussions provided social contexts where either the teacher scaffolded

Students in the whole class situation to conceptualize their thinking or students assisted each other in peer groups to explore more freely and generate diverse vocabulary and ideas for the writing tasks.

Zhang and Vukelich (1998) investigated the influences of prewriting activities on the writing quality of male and female students with varying academic achievement across four grade levels.

Participants were public school students in grades 4, 6, 9, and 11. At each grade level students were assigned to one of two groups: writing with or without prewriting activities. Researchers rated each student's writing piece holistically and on five quality aspects of writing.

Results indicated that on average, students who wrote with prewriting activities performed better than students who wrote without prewriting activities. Students' gender and academic achievement level had strong influences on the effectiveness of prewriting, with females consistently scoring higher than males

Ismail (2002) investigated the effects of an integrated process-product approach to writing instruction on developing the creative writing skills of first-year EFL majors at Sohag faculty of Education.

The sample of the study involved seventy-four students from Sohag Faculty of Education (Egypt). They were randomly chosen from the population of first-year EFL majors and randomly assigned to a control group and an experimental group.

The experimental group students were taught writing using the integrated process-product approach while the control students did not receive such instructional treatment.

Findings of the study indicated that the process-product approach to writing instruction had significant effects on improving the experimental group EFL majors knowledge of the writing processes, their creative writing skills and products as well as their attitudes towards writing in English as a foreign language. The study recommended that 1- EFL teachers at various educational levels be trained in the implementation of the integrated process-product approach to writing instruction. 2- pre-service as well as in service EFL teachers be systematically trained in fostering and evaluating creativity in the language arts especially writing.

Hashem (2005) investigated the effectiveness of a proposed program in developing the creative thinking abilities of Egyptian third preparatory pupils in English language.

Tools of the study included an opinion- seeking questionnaire, the suggested program and the teacher's guide, the creative thinking abilities test and an observation sheet.

The sample of the study consisted of 132 pupils classified randomly into experimental and control groups.

The experimental procedures of the suggested program lasted for eight weeks. Ten hypotheses were presented by the researcher to test their validity.

To implement the suggested program, the researcher followed several strategies including brainstorming, creative problem solving, discussion, role playing, simulation, self-assimilation, open- ended stories, wordless stories, language games, puzzles and riddles, attribute listing, and skits (innovating a comic solution to a certain character).

Results revealed the effectiveness of the suggested program in developing pupils' creative thinking abilities.

Pupils of the experimental group performed much better on the post-test in the overall creative thinking abilities (fluency, flexibility, originality and elaboration) than the control group pupils.

Shorofat (2007) investigated the effect of using brainstorming and 'synectis' in developing creative writing skills of ninth female students and their attitudes towards writing in Arabic. 
The study sample consisted of 132 students -from Zarqa Governorate Schools- and they were classified randomly into one control group and two experimental groups, one of them used brainstorming and the other group used 'synectis'.

The researcher applied a pre-test on the three groups, and then she taught them during a period of five weeks, after that she applied the post test to investigate the effectiveness of the used strategies.

Results showed that using brainstorming and 'synectis' were effective in developing students' creative writing skills in terms of content, organization, style and mechanics of writing. Results also showed that there was no effect of the used strategies on students' attitudes towards writing.

Banat (2007) investigated the effectiveness of a program based on the process approach and learning style in developing EFL writing skills among Jordanian secondary stage students.

The sample of the study consisted of 90 male first secondary class, scientific stream students enrolled in the academic year 2006- 2007 in public schools in the city of Jarash, Jordan.

The students were allocated in three intact classes. The classes were chosen randomly. Two classes served as experimental groups and the third as a control group.

The students in the first experimental group received instruction through a program based on both the process approach to writing and learning style preference for developing their writing skills.

The students in the second experimental group received instruction through a program based on the process approach to writing only.

In the control group the students received instruction through the traditional method of teaching writing (the product approach). A pre-post test was given to the three groups before and after the treatment.

Findings of the study showed that the three groups achieved tangible progress in their writing skills on the post test as compared to the pretest. Moreover the two experimental groups outperformed the control group on the posttest in overall writing performance. Nevertheless, the process approach and learning styles group (the first experimental group) was better than the process approach group (the second experimental group) on the post test. This means that the program proved to be effective in developing EFL secondary stage students' writing skills.

\section{Tools of the Study and Procedures}

1. Design of the Study:

The study followed the Quasi- Experimental Design. Four classes were chosen randomly from Amman public education schools. Two classes served as an experimental group and the other ones as control.

Students of the experimental group received instruction through the proposed technique (brainstorming), whereas students of the control group received instruction through the traditional method.

A pre-post test was administered to both groups before and after the implementation of the proposed technique on the experimental group.

2. Sample of the Study:

The sample of the study, as shown in table (1), comprised 84 first secondary grade students allocated in four classes, randomly selected from Amman public education schools. Two classes served as an experimental group and the other ones as control

The students' average age was 17 years old. According to their school files, all the students were from a nearly similar socio- economic environment.

TABLE (1)

DiSTRIBUTION OF STUDY SAMPLE

\begin{tabular}{|l|l|l|l|l|}
\hline No. & School & $\begin{array}{l}\text { Number of } \\
\text { Sections }\end{array}$ & $\begin{array}{l}\text { Number of } \\
\text { Students }\end{array}$ & Method of Te aching \\
\hline 1 & \multirow{2}{*}{ Abu Alia School } & 1 & 23 & Traditional Method \\
\cline { 3 - 6 } & & 1 & 19 & Brainstorming \\
\hline 2 & Sharif Huss ein bin & 1 & 23 & Traditional Method \\
\cline { 3 - 6 } & Ali School & 1 & 19 & Brainstorming \\
\hline total & & $\mathbf{4}$ & $\mathbf{8 4}$ & \\
\hline
\end{tabular}

3. The Essay Writing Skills Checklist:

3.1. Purpose of the checklist:

The checklist aimed at identifying the essay writing skills necessary for first secondary grade students.

3.2. Content of the checklist:

Having reviewed the related literature on developing students' writing skills, the researcher designed an essay writing skills' checklist and submitted it to specialized jury members in the of English Language Teaching (ELT) so as to determine the degree of importance of each skill on the checklist..

The list included 16 skills classified under four categories: content and organization, language use, mechanics of writing, and creative abilities.

The jury members stated that the skills included in the checklist were generally adequate and appropriate to its purpose. Still, some skills were deleted since they had been considered above the first secondary grade students' level.

The checklist was modified according to the jury members' suggestions to be as follows: 


\begin{tabular}{|l|l|l|}
\hline No. & \multicolumn{1}{|c|}{ The Criterion } & \multicolumn{1}{c|}{ Related Skills } \\
\hline $1-$ & $\begin{array}{l}\text { Content and } \\
\text { Organization }\end{array}$ & \\
\hline & & 1- Clarity of ideas. \\
\hline & & 2- Relevant supporting details. \\
\hline & & 3- Divid ing the essay into introduction, body and conclusion. \\
\hline & & 4- Moving s moothly from introduction to body to conclusion. \\
\hline & & 5- Well- organized paragraphs. \\
\hline $2-$ & Mechanics of Writing & 6- Log ically- sequenced ideas. \\
\hline & & 1- Punctuation. \\
\hline & & 2- Spelling. \\
\hline & & 3 - Grammar. \\
\hline $3-$ & Language Use & \\
\hline & & 1-Appropriate choice of words. \\
\hline & & 2-Accurate use of expressions. \\
\hline $4-$ & Cre ative Abilities & \\
\hline & (Fluency) & 1-Many ideas. \\
\hline & (Flexibility) & 2-Varied ideas and points of view. \\
\hline & (Originality) & 3-Unique titles and ideas. \\
\hline & (Elaboration) & 4- Embellishing ideas with details. \\
\hline
\end{tabular}

4. The Pre- Post Essay Writing Test:

4.1. Purpose of the test:

The test aimed at measuring the essay writing skills of firs secondary grade students in English.

The test was administered to both groups before and after the implementation of the proposed technique (brainstorming).

4.2. Validity of the test:

Test validity refers to the degree to which the test actually measures what it claims to measure.

To ensure validity of the test, the researcher submitted it, in its initial form, to a number of specialized jury members.

The jury members were asked to comment on:

- Clarity of the test instructions.

-Suitability of the topics to the level of first secondary grade students.

- Clarity of the questions.

The test was modified according to the Jury members' comments and suggestions.

4. 3. Reliability of the test:

Reliability is the extent to which the measurement of the test remains consistent over repeated tests on the same subjects under identical conditions.

To establish the reliability of the test, it was administered to a sample of 15 firs secondary grade students other than the sample of the study. Then, the same test was administered to the same group under nearly similar conditions after two weeks.

The reliability coefficient of the test was estimated using Cronbach Alpha Formula. The estimated value was (0.89), which is considered reliable for the purpose of the current study.

4.4. Duration of the Test:

Duration of the creative writing test was estimated by calculating the time spent by the fastest and the slowest students in answering the test divided by 2 . Thus, the time allotted for the test was:

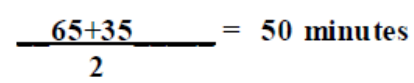

5. The Scoring Scale:

5.1. Purpose of the scoring scale:

After reviewing a number of writing scoring scales, the researcher prepared the current study's scoring scale to evaluate each skill on the pre- post essay writing test. Students' essays were scored out of 75 points as follows: Content and Organization 30, Mechanics of Writing 15, Language Use 10, Creative Abilities 20. Each skill has a five- level scoring scale ranging from excellent to poor.

5.2. Validity of the scoring scale:

To ensure validity of the scale, the researcher submitted it, in its initial form, to a number of specialized jury members in the field of curricula and instruction (TEFL).

The jury members were asked to comment on the suitability of the scale to assess first secondary grade students' performance on essay writing pre- post test.

The scale was modified according to the jury members' comments and suggestions.

5.3. Reliability of the scoring scale:

To establish the reliability of the scoring scale, the researcher followed two ways:

1- The inter-reliability of raters: The researcher and other two experienced raters used the scoring scale to evaluate 
students' writing.

A sample of ten papers was chosen randomly and scored by the researcher and other two raters independently. The inter-raters' reliability was computed using Cronbach Alpha Formula. It was (0.89), which is considered reliable for the purpose of the current study. (Table 2)

TABLE (2)

THE INTER- RATERS' RELIABILITY

\begin{tabular}{|l|c|}
\hline \multicolumn{1}{|c|}{ The inter- rater correlation } & \multicolumn{1}{c|}{ Correlation coefficient } \\
\hline $\begin{array}{l}\text { The inter-rater correlation between the first and } \\
\text { the second rater. }\end{array}$ & 0.89 \\
\hline $\begin{array}{l}\text { The inter-rater correlation between the second and } \\
\text { the third rater. }\end{array}$ & 0.88 \\
\hline $\begin{array}{l}\text { The inter-rater correlation between the first and } \\
\text { the third rater. }\end{array}$ & 0.89 \\
\hline Aver age & 0.89 \\
\hline
\end{tabular}

2- Intra-reliability of the rater: A sample of students' papers (fifteen papers) was scored by the researcher himself according to the scoring scale. The researcher scored the same papers after two weeks. The intra- rater reliability coefficient was computed through Cronbach Alpha Formula, it was (0.96), which is considered high and reliable for the purpose of the current study.

6. Equivalence of the experimental and control groups:

To establish the equivalence of the two groups, the pre-essay writing test was administered to the experimental and control groups before applying the proposed technique (brainstorming) to the experimental group.

The t- test was implemented to compare the means of both groups on the pre- essay writing.

Table (3) shows the results of the pre- administration of the essay writing test on the experimental and control groups.

TABLE (3)

SCORES OF THE EXPERIMENTAL AND CONTROL GROUPS ON THE PRE-TEST

\begin{tabular}{|c|l|c|c|c|c|c|c|}
\hline \multicolumn{2}{|c|}{ Pair } & N & Mean & $\begin{array}{c}\text { Standard } \\
\text { Deviation }\end{array}$ & T & D.F & P-Value \\
\hline \multirow{2}{*}{ Es say } & Experimental & 42 & 32.50 & 8.275 & \multirow{2}{*}{0.350} & 82 & 0.728 \\
\cline { 2 - 9 } & Control & 42 & 32.00 & 6.487 & & \multirow{2}{*}{0.350} \\
\hline
\end{tabular}

Based on the above table, it could be concluded that the two groups were equivalent in their essay writing skills. There was no statistically significant difference between the mean scores of both groups, thus, any later significant change in students' essay writing skills will be due to the effect of the implementation of the brainstorming technique.

7. The Statistical Methods:

The current study used the following statistical methods:

1- T- Test:

- To measure the difference between the mean scores of the experimental group on the pre- post essay writing test.

- To measure the difference between the mean scores of the experimental and control groups on the post - essay writing test.

2- Etta Square Equation. To measure the effect size, the following equation was used:

$$
\eta^{2}=-\frac{\mathbf{T}^{2}}{\mathbf{T}^{2}+\text { D.F. }}
$$

\section{DATA COLLECTION AND RESUlts OF THE STUDY}

\section{A. The First Hypothesis}

"There is statistically significant difference between the mean scores of the experimental group and the control group on the post- test in essay writing in favor of the experimental group ".

TABLE (4)

SCORES OF THE EXPERIMENTAL AND CONTROL GROUPS ON THE POST-TEST IN ESSAY WRITING

\begin{tabular}{|c|c|c|c|c|c|c|c|c|}
\hline Pair & $\mathrm{N}$ & Mean & $\begin{array}{c}\text { Std. } \\
\text { Deviation }\end{array}$ & D.F & $\mathrm{T}$ & $\eta 2$ & $\begin{array}{c}\text { P- } \\
\text { Value }\end{array}$ & $\begin{array}{c}\text { Le vel of } \\
\text { Significance } \\
\text { at } 0.05\end{array}$ \\
\hline Exp. & 42 & 38.74 & 10.32 & 82 & 2.836 & 0.071 & 0.006 & 1.66 \\
\hline Cont. & 42 & 33.76 & 7.50 & 82 & \\
\hline
\end{tabular}

Having analyzed scores of the experimental group and control group on the post-test in essay writing, the researcher concluded that there was statistically significant difference at 0.05 level between the mean scores of the experimental and control groups on the post -test in essay writing in favor of the experimental group. T value (2.836), $\eta 2$ value (0.071) and level of significance at 0.05 equaled (1.66).

This proves that the proposed technique had a positive effect on developing essay writing skills of the experimental 
group students, since that students of the experimental group, who received training through the proposed technique showed progress in their essays writing skills in terms of content and organization, mechanics of writing, language use as well as skills emerged from creative thinking abilities (fluency, flexibility, originally and elaboration).

\section{B. The Second Hypothesis}

"There is statistically significant difference between the mean scores of the experimental group on the pre- test and post- test in essay writing in favor of the post- test scores ".

TABLE (5)

SCORES OF THE EXPERIMENTAL GROUP ON THE PRE-TEST AND POST-TEST IN ESSAY WRITING

\begin{tabular}{|l|c|c|c|c|c|c|c|c|}
\hline Pair & $\mathrm{N}$ & Mean & $\begin{array}{c}\text { Std. } \\
\text { De viation }\end{array}$ & D.F & $\mathrm{T}$ & $\eta 2$ & $\begin{array}{c}\text { P- } \\
\text { Value }\end{array}$ & $\begin{array}{c}\text { Level of } \\
\text { Significance } \\
\text { at } 0.05\end{array}$ \\
\hline T1 & 42 & 32.50 & 8.28 & 41 & 9.915 & 0.650 & 0.000 & 1.67 \\
\hline T2 & 42 & 38.74 & 10.32 & 42 & \\
\hline
\end{tabular}

Having analyzed scores of the experimental group on the pre- post test in essay writing, the researcher concluded that there was statistically significant difference at 0.05 level between the mean scores of the experimental group on the pre-test and post-test in essay writing in favor of the post-test scores. T value (9.915), $\eta 2$ value $(0.650)$ and level of significance at 0.05 equaled (1.67).

This also proves that the proposed technique (brainstorming) had a positive effect on developing essay writing skills of the experimental group students. Students of experimental group showed progress in their written essays in terms of content and organization, mechanics of writing, language use and skills emerged from creative thinking abilities (fluency, flexibility, originality and elaboration)

\section{CONCLUSION}

Results of the study supported the two hypotheses presented by the researcher. It was proved that the experimental group performed much better on the post- essay writing test than the control group.

Thus, the proposed technique (brainstorming), had a positive effect on developing first secondary grade students' essay writing skills in terms of content and organization, mechanics of writing, language use and skills emerged form creative thinking abilities (fluency, flexibility, originality and elaboration).

The researcher believes that the use of the brainstorming technique highly contributed to enabling learners generate ideas, exchange opinions and crystallize new thoughts about the raised topics, a fact that positively affected their performance on the post-essay writing test.

In addition, using the brainstorming technique motivated learners to get involved in the learning process and express themselves freely without hesitation, since they were told that their ideas will not be judged during the brainstorming session, thus they felt free while generating their ideas and came up with unique and unexpected thoughts.

\section{RECOMMENDATIONS}

Based on findings of the study, the researcher recommends the Jordanian Ministry of Education to:

1- Place more emphasis on developing students' writing skills in general, and essay writing skills in particular.

2-Take the brainstorming technique into account while designing English language curricula due to its role in motivating the students to get involved in the learning process.

Moreover, the researcher recommends teachers of English language to

1- Place more emphasis on teaching writing as a process not only as a product.

2- Place more emphasis on the pre- writing stage due to its vital role in the writing process.

\section{REFERENCES}

[1] Aggarwal, J. (2001). Principles, Methods and Techniques of Teaching (2ed edition), Vikas Publishing House.

[2] Al Abed Al Haq, F. (1994). Discourse Problems in Argumentative Writing. World Englishes, 13(3), 307-323.

[3] Alsouqi, S. (2001). The Effect of Using Computers in Teaching of L2 Composition on the Writing Performance of Tenth Grade Students in Amman Private Schools, Unpublished M.A. thesis, Faculty of Graduate Studies, University of Jordan, Amman, Jordan, 117-120.

[4] Anna, C., Bob, J. and Mike, L. (2001). Creativity in Education, British Library, London, UK.

[5] Banat, S. (2007). The effect of a Program Based on the Process Approach and Learning Style on Developing EFL Writing Skills Among Jordanian Secondary Stage Students, Unpublished Ph.D Thesis, Amman Arab University for Graduate Studies, Amman, Jordan.

[6] Bello, T. (1997). Writing Topics for Adult ESL Students, Paper presented at the 31st Annual Teachers of English to Speakers of Other Language Convention, Orlando, Fl, USA.

[7] Bransford, J. and Stein, B. (1984). The IDEAL Problem Solver: A guide for Improving Thinking, Learning, and Creativity, W.H. Freeman, New York.

[8] Brown, H. D. (2000). Principles of Language Learning and Teaching, 4th ed, Addison Wesley Longman, New York. 
[9] Botle, L. (1997).Assessing Mathematical Knowledge with Concept Maps and Interpretive Essays. (ERIC Documents Reproduction Services No. ED 408160)

[10] Bourke, J. (1992). The Case for Problem Solving in Second Language Learning, (ERIC Document Reproduction Service, No. ED 353822)

[11] Colantone, L. (1998). Improving Creative Writing, Unpublished M.A thesis, Saint Xavier University, Chicago, Illinois, USA.

[12] Darayseh, A. (2003). The Effect of a Proposed Program Based on Semantic Mapping and Brainstorming Strategies on Developing the English Writing Ability and Attitudes of the First Scientific Secondary Students, Unpublished Ph.D. Thesis, Amman Arab University for Graduate Studies, Amman, Jordan.

[13] El Abed, W. (1991). The Effect of Selected Prewriting Activities on the Quantity and Quality of First Year Student Composition in Vocational Training Centers, Unpublished M.A. thesis, Yarmouk University, Jordan.

[14] Elaine, F. (2002). The Effects of Four Writing Strategies on Fifth Graders' Production of Written Ideas across Three Aims of Discourse, (ERIC Document Reproduction Service. No. ED 458596)

[15] Fisher, R. and Williams, M. (2004). Unlocking Creativity: A Teacher's Guide to Creativity Across the Curriculum, David Fulton Publishers Ltd., London.

[16] French, N. and Rhoder, C. (1992).Teaching Thinking Skills. Garland Publication, INC, NY, USA, 238

[17] Gaber. A. (2003). The Effectiveness of a Suggested Program Based on the Whole Language Approach in Developing StudentTeachers' Essay Writing Skills, Unpublished M.A Thesis, Ain Shams University, Egypt, 63-65.

[18] Garnett, S. (2005).Using Brainpower in the Classroom. Routledge, New York, USA.

[19] Hashem, L. (2005). The Effectiveness of a Suggested Programme in Developing Creative Thinking in English Language for the Students of the Preparatory Cycle, Unpublished Ph. D Thesis, Institute of Educational Studies, Cairo University, Egypt.

[20] Harp, B. and Brewer, J. (1996). Reading and Writing: Teaching for the Connections. Orlando, Haircourt Brace College Publisher.

[21] Holden, M. (1996). Effectiveness of Two Approaches to Teaching Writing in Improving Students' Knowledge of English Grammar, (ERIC Document Reproduction Service. No. ED366006).

[22] Houston, H. (2006). A Brainstorming Activity for ESL/EFL Students, City University of Hong Kong. The Internet TESL Journal, Vol. XII, No. 12.

[23] Ismail, A. (2002). The Effect of an Integrated Process-Product Approach to Teaching Writing on Developing The Creative Writing Skills of First-Year EFL Majors at Sohag Faculty of Education, Unpublished Ph.D Thesis, Sohag University, Egypt.

[24] Joyce, F. and Carol, R. (1992). Teaching Thinking Skills, Garland Publication, INC, NY, USA.

[25] Khwaileh, K. (1991). A Comparative Study of the Effect of Some Prewriting Activities on the Quantity and Quality of Paragraphs Written by Ninth- Grade Students in Ramtha, Unpublished M.A. Thesis, Yarmouk University, Irbid, Jordan.

[26] Kirby, D. and Liner, T. (1988). Inside out, Developmental Strategies for Teaching Writing, Boynton, Cook Publishers, Inc.

[27] Lin, J. P. (1999). A Creative Writing Classroom, Taepei, Psychological Press.

[28] Lindsay, P. (2000). Teaching English World Wide: A New practical Guide to Teaching English, Alta Book Center Publishers, San Francisco.

[29] Loehle, C. (1996). Thinking Strategically, Cambridge University Press, London, UK, 41

[30] Long, E. (1991). The Effects of an Integrated Language Arts Curriculum on the Writing Improvement of First-Grade Students, Illinois State University, D.A. I. , Vol. 51, No. 8.

[31] Manktelow, J. (2003). Creativity Tools, Station Rd. UK, 18-25.

[32] Nichols, C. (2006). Creative Writing in EFL, North Dakota State University, USA.

[33] Reynolds, A. (1983). The Effects of Teaching Expressive Writing (Integrated within the writing process) on the Improvement of Student Writing Skills at the High School Level, Dissertation Abstracts International, 44 (4), 10-11.

[34] Richard, J. (1992). The Language Teaching Matrix, Cambridge University Press, New York.

[35] Shi, L. (1998). Effects of prewriting discussions on adult ESL students' compositions. Journal of Second Language Writing, Volume 7, Number 3, 319-345.

[36] Shorofat, A. (2007). The effect of Using Syncetics and Brainstorming on Ninth Grade Creative Writing, Unpublished Ph.D. Thesis, the University of Jordan.

[37] Smith, D. (2000). Writing Instruction: Current Practices in the Classroom, ERIC Document Reproduction Services No. ED. 156- 358

[38] Smoke, T. (1987). A Writer's Workbook. TESOL Quarterly Journal, Vol. 22, 3, New York, 62-68.

[39] Stephenson, C. (2000). Teaching Problem Solving and Design, University of Toronto, CS Summer Institute.

[40] Tse, S. and Shum, W. (2001). Teaching Chinese Language Writing in Secondary Schools: Theory and Design, University of Hong Kong, The Journal of Creative Behavior, V. 35, N. 4, 249.

[41] Zhang, L. and Vukelich, C. (1998). Prewriting Activities and Gender: Influences on the Writing Quality of Male and Female Students, ERIC Document Reproduction Service No. ED 42297).

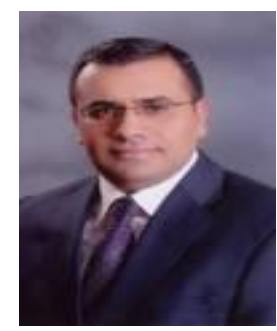

Salem Saleh Khalaf Ibnian, born in Amman, Jordan in 1978, holds a Ph. D. degree in TEFL from Cairo University in 2009, an M. A. in TEFL from the University of Jordan in 2004

$\mathrm{He}$ is currently assistant professor at Middle East University, Jordan. His research interests include EFL teaching, teaching and testing, and ESP.

Dr. Salem is member of Association of Professors of English and Translation at Arab Universities (APETAU) 